\title{
Pedagogical Practice as an Essential Step for Development of Pedagogical Competencies
}

\author{
Meri Grabska, Srbuhi Gevorgyan, Stepan Grabski \\ Armenian State Pedagogical University After Khachatur Abovian \\ Armenia
}

\begin{abstract}
Armenia signed the Lisbon Recognition Convention on Education in 1997, and joined the Bologna Process in 2005, thus becoming a full member of the European Higher Education Area. As a result of joining the Bologna System, we adopted competence-based education, which put new challenges both for high school education and secondary school teaching. In the traditional frame of education in Armenia, the teacher was considered the main transmitter of knowledge. Due to education reforms, this traditional frame was replaced by the competence-based approach, where the four areas of the competencies (learning to know, learning to do, learning to live together and learning to be) form the basis on which the teacher constructs his professional ability to apply them in everyday work and develop professional skills. The internationalization of the education process arose different problems. On one hand, some of the specialists think that the changes have formal character, they are obligatory, superficial and don't change the traditional character of the teaching process. On the other hand, the students receive a good deal of modern theoretical information on the competencies at their university classes. So, we face a contradiction between theoretical knowledge and its practical application.
\end{abstract}

\section{Introduction}

This paper is focused on the study of competencebased approaches in the educational process in the context of the Bologna Process. The training of the future teachers demanded a new level of knowledge as well as practical skills. The problem is what kind of knowledge the future teachers get during their study and how well they are prepared to apply this knowledge in practice. So, what we need nowadays is the competence-based education that includes the type of knowledge skills and values that a professional must possess for a successful realization of the teaching process.

In the modern educational system, "teachers are expected to process and evaluate knowledge relevant to their core professional practice and to regularly update their profession's knowledge base. This challenge is situated in a rapidly changing educational system, which is expected to deliver on " 21 st-century skills" in increasingly more diverse classrooms, and conditioned by expanding research-based scientific knowledge base on teaching and learning. This process of continuous renewal of teachers' professional knowledge is an important part, maybe the most important, of teachers' professionalization [1]. These new challenges for the professionals to reevaluate their knowledge, their teaching methods, as well as other professional skills, need some deep theoretical and experimental study. The teachers need to recognize and compare what type of knowledge and skills they already possess and to what extent they need to be updated according to modern standards.

\section{The Main Objectives of the Study}

The pedagogical practice process is of great importance for the students at least for the following:

- The main objective of the pedagogical practice is the practical implementation of the students' theoretical knowledge gained at the University.

- Development of a professional experience necessary for future work.

- Development of required skills to use creatively the new technologies in the educational process.

- To develop the necessary skills to make reflections and find the gaps between their theoretical knowledge and practical work.

- To have an opportunity to work under the supervision of the experienced teachers and, thus, reflect both on the teachers' style of work and the process of realization of their theoretical knowledge in practice.

- The pedagogical practice gives the student a good opportunity to compare the demands which are put to the new competence-based teaching and the realization of those demands in the real teaching process.

In this sense, the main objective of the current investigation is to analyse the dynamics of change in the evolution of professional competencies by the students before and after their pedagogical practice at schools and to compare them with the evaluation of 
the competencies by the teachers who guided their professional practice.

The reason of the choice both of the teachers and the students is that they have foreign languages as their specialization and commonly are considered to be the most advanced part of the professionals who can easily get acquainted with the latest information in their professional area. In this work, we want to give a brief, but detailed review of the results we obtained during our research.

\section{Technique}

The study was carried out by the help of Questionnaire designed by the Spanish investigators R.Ferrández-Berrucco and L. Sánchez-Tarrazaca [2]. The evaluation scales of Questionnaire are based on Likert-scale for the interpretation of the mean values. The study has been carried out in four stages:

- The students evaluated the teachers' professional competencies before the pedagogical practice by the help of Questionnaire.

- The same students evaluated professional competencies with the same Questionnaire by the end of the practice (after four months).

- The foreign language teachers evaluated the professional competencies by the help of the same Questionnaire at the beginning of the pedagogical practice of the students.

- By the end of the practice, the students were asked to present their reflections on the evaluation.

\section{Data Analysis and Discussion}

The evaluation process included the period from 2016-2019 and more than 200 students from the Department of Foreign Languages of Armenian State Pedagogical University (ASPU) and the same number of school teachers with whom the students were working, answered Questionnaire.

Group 1 represents the evaluations of the students before the pedagogical practice.

Group 2 represents the answers of the teachers who guided the pedagogical practice of the students.

Group 3 represents the answers of the students by the end of the pedagogic practice.

The results of the evaluations are demonstrated on the tables.

Table 1. Subject competencies (learning to know)

\begin{tabular}{|l|c|c|c|}
\hline \multirow{2}{*}{ Item } & Group 1 & Group 2 & Group 3 \\
\cline { 2 - 4 } & Mean & Mean & Mean \\
\hline $\begin{array}{l}\text { 1. Subject } \\
\text { competencies } \\
\text { (learning to know) }\end{array}$ & \multicolumn{3}{|c}{} \\
\hline
\end{tabular}

\begin{tabular}{|l|c|c|c|}
\hline $\begin{array}{l}\text { 1.1 Knowing the } \\
\text { content of my subject }\end{array}$ & 3.0 & 2.94 & 2.94 \\
\hline $\begin{array}{l}\text { 1.2 Being up to date } \\
\text { with innovations in } \\
\text { the subject }\end{array}$ & 2.95 & 2.50 & 2.60 \\
\hline $\begin{array}{l}\text { 1.3 Knowing the } \\
\text { history and } \\
\text { development of the } \\
\text { subject I teach }\end{array}$ & 3.0 & 3.0 & 3.0 \\
\hline $\begin{array}{l}\text { 1.4 Knowing how to } \\
\text { transfer my } \\
\text { knowledge so students } \\
\text { learn }\end{array}$ & 3.0 & 3.0 & 3.0 \\
\hline $\begin{array}{l}\text { 1.5. Knowing how to } \\
\text { plan and organise } \\
\text { content }\end{array}$ & 3.0 & 3.0 & 3.0 \\
\hline $\begin{array}{l}\text { 1.6. Being trained in } \\
\text { pedagogy and } \\
\text { psychology for young } \\
\text { people }\end{array}$ & 3.0 & 2.67 & 2.80 \\
\hline $\begin{array}{l}\text { 1.7. Knowing about } \\
\text { innovative } \\
\text { educational strategies }\end{array}$ & 3.0 & 2.70 & 2.80 \\
\hline $\begin{array}{l}\text { 1.8. Knowing about } \\
\text { ICT }\end{array}$ & 3.0 & 2.70 & 2.75 \\
\hline $\begin{array}{l}1.9 . \text { Having a high } \\
\text { level of linguistic } \\
\text { competence in official } \\
\text { languages }\end{array}$ & 2.99 & 2.72 & 2.70 \\
\hline $\begin{array}{l}1.10 . \text { Knowing a } \\
\text { foreign language well } \\
\text { enough to teach }\end{array}$ & 2.90 & 2.83 & 2.70 \\
\hline
\end{tabular}

Table 2. Methodological competencies (learning to do)

\begin{tabular}{|l|c|c|c|}
\hline \multirow{2}{*}{ Item } & Group 1 & Group 2 & Group 3 \\
\cline { 2 - 4 } & Mean & Mean & Mean \\
\hline $\begin{array}{l}\text { 2. Methodological } \\
\text { competencies } \\
\text { (learning to do) }\end{array}$ & \multicolumn{2}{|c|}{} \\
\hline $\begin{array}{l}\text { 2.1. Managing the } \\
\text { classroom climate } \\
\text { (working atmosphere, } \\
\text { confidence, etc.) }\end{array}$ & 3.0 & 3.0 & 3.0 \\
\hline $\begin{array}{l}\text { 2.2. Applying } \\
\text { strategies enabling } \\
\text { students to work in } \\
\text { groups }\end{array}$ & 3.0 & 2.90 & 2.80 \\
\hline $\begin{array}{l}\text { 2.3. Fostering } \\
\text { dynamics for class } \\
\text { cohesion }\end{array}$ & 3.0 & 2.93 & 2.90 \\
\hline $\begin{array}{l}\text { 2.4. Responding to } \\
\text { problems of diversity } \\
\text { in the classroom }\end{array}$ & 3.0 & 2.92 & 2.89 \\
\hline $\begin{array}{l}\text { 2.5. Developing } \\
\text { initiatives for students } \\
\text { with education needs }\end{array}$ & 3.0 & 2.67 & 2.70 \\
\hline $\begin{array}{l}\text { 2.6. Knowing how to } \\
\text { resolve conflict in the } \\
\text { classroom }\end{array}$ & 3.0 & 2.98 & 2.99 \\
\hline $\begin{array}{l}\text { 2.7. Holding tutorials } \\
\text { and being able to give }\end{array}$ & 2.97 & 2.77 & 2.70 \\
\hline
\end{tabular}




\begin{tabular}{|l|c|c|c|}
\hline $\begin{array}{l}\text { academic and } \\
\text { professional guidance }\end{array}$ & & & \\
\hline $\begin{array}{l}\text { 2.8. Introducing } \\
\text { improvements after } \\
\text { reflecting on my } \\
\text { practices }\end{array}$ & 3.0 & 2.95 & 2.93 \\
\hline $\begin{array}{l}\text { 2.9. Proficiency in } \\
\text { verbal and non-verbal } \\
\text { communication } \\
\text { competencies }\end{array}$ & 3.0 & 2.90 & 2.94 \\
\hline $\begin{array}{l}\text { 2.10. Using various } \\
\text { student evaluation } \\
\text { techniques and } \\
\text { systems }\end{array}$ & 2.98 & 2.75 & 2.78 \\
\hline $\begin{array}{l}2.11 \text {. Exploring } \\
\text { students' previous } \\
\text { knowledge with initial } \\
\text { evaluation }\end{array}$ & 3.0 & 2.70 & 2.73 \\
\hline $\begin{array}{l}2.12 . \text { Following up } \\
\text { students' learning } \\
\text { levels }\end{array}$ & 3.0 & 2.80 & 2.79 \\
\hline $\begin{array}{l}2.13 . \text { Using } \\
\text { evaluation as a tool to } \\
\text { improve learning }\end{array}$ & 3.0 & 2.82 & 2.80 \\
\hline $\begin{array}{l}2.14 . \text { Designing } \\
\text { teaching programmes }\end{array}$ & 2.95 & 2.55 & 2.50 \\
\hline $\begin{array}{l}2.15 . \text { Being able to } \\
\text { prepare teaching } \\
\text { materials }\end{array}$ & 3.0 & 2.70 & 2.72 \\
\hline $\begin{array}{l}2.15 . \text { Being able to } \\
\text { prepare teaching } \\
\text { materials }\end{array}$ & 3.0 & 2.70 & 2.72 \\
\hline $\begin{array}{l}2.16 . \text { Being proficient } \\
\text { in ICT for use as a } \\
\text { classroom resource }\end{array}$ & 3.0 & 2.75 & 2.77 \\
\hline $\begin{array}{l}2.17 . \text { Educating } \\
\text { students in } \\
\text { technological } \\
\text { information and } \\
\text { communication }\end{array}$ & 3.0 & 2.77 & 2.78 \\
\hline
\end{tabular}

Table 3. Social Competencies (learning to live together)

\begin{tabular}{|l|c|c|c|}
\hline \multirow{2}{*}{\multicolumn{1}{|c|}{ Item }} & Group 1 & Group 2 & Group 3 \\
\cline { 2 - 4 } & Mean & Mean & Mean \\
\hline $\begin{array}{l}\text { 3. Social } \\
\text { Competencies } \\
\text { (learning to live } \\
\text { together) }\end{array}$ & \multicolumn{2}{|c|}{} \\
\hline $\begin{array}{l}\text { 3.1 Stimulating } \\
\text { students to formulate } \\
\text { rules for living } \\
\text { together }\end{array}$ & 3.0 & 2.70 & 2.74 \\
\hline $\begin{array}{l}\text { 3.2. Strengthening } \\
\text { students' attitudes of } \\
\text { critical citizenship }\end{array}$ & 3.0 & 2.50 & 2.47 \\
\hline $\begin{array}{l}\text { 3.3. Having an } \\
\text { attitude of } \\
\text { collaboration with the } \\
\text { educational } \\
\text { community }\end{array}$ & 3.0 & 2.67 & 2.60 \\
\hline
\end{tabular}

\begin{tabular}{|l|c|c|c|}
\hline $\begin{array}{l}\text { 3.4. Working in teams } \\
\text { with other } \\
\text { professionals }\end{array}$ & 3.0 & 2.89 & 2.70 \\
\hline $\begin{array}{l}\text { 3.5. Participating in } \\
\text { school/institutional } \\
\text { projects }\end{array}$ & 3.0 & 2.60 & 2.61 \\
\hline $\begin{array}{l}\text { 3.6. Facilitating } \\
\text { communication with } \\
\text { students and families }\end{array}$ & 3.0 & 2.95 & 2.90 \\
\hline $\begin{array}{l}\text { 3.7. Respecting and } \\
\text { being able to apply } \\
\text { education system } \\
\text { regulations }\end{array}$ & 3.0 & 2.71 & 2.70 \\
\hline $\begin{array}{l}\text { 3.8. Fostering the } \\
\text { school's relationship } \\
\text { with agents in the } \\
\text { community }\end{array}$ & 2.92 & 2.60 & 2.62 \\
\hline $\begin{array}{l}\text { 3.9. Participating in } \\
\text { educational research } \\
\text { projects }\end{array}$ & 3.0 & 2.40 & 2.39 \\
\hline
\end{tabular}

Table 4. Personal competencies (learning to be)

\begin{tabular}{|l|c|c|c|}
\hline \multicolumn{1}{|c|}{ Item } & Group 1 & Group 2 & Group 3 \\
\cline { 2 - 4 } & Mean & Mean & Mean \\
\hline $\begin{array}{l}\text { 4. Personal } \\
\text { competencies } \\
\text { (learning to be) }\end{array}$ & \multicolumn{2}{|c|}{} \\
\hline $\begin{array}{l}\text { 4.1. Knowing myself } \\
\text { and my capabilities } \\
\text { well }\end{array}$ & 3.0 & 2.99 & 3.0 \\
\hline $\begin{array}{l}\text { 4.2. Knowing how to } \\
\text { take decisions } \\
\text { individually }\end{array}$ & 3.0 & 2.98 & 3.0 \\
\hline $\begin{array}{l}\text { 4.3. Taking on } \\
\text { responsibilities in the } \\
\text { school, if necessary }\end{array}$ & 3.0 & 3.0 & 2.80 \\
\hline $\begin{array}{l}\text { 4.4. Fostering a } \\
\text { climate of respect and } \\
\text { freedom of expression }\end{array}$ & 3.0 & 2.50 & 2.41 \\
\hline $\begin{array}{l}\text { 4.5. Having self- } \\
\text { control and being } \\
\text { emotionally balanced, } \\
\text { resisting frustration }\end{array}$ & 3.0 & 3.00 & 2.80 \\
\hline $\begin{array}{l}\text { 4.6. Teaching students } \\
\text { values (and being } \\
\text { aware of them) }\end{array}$ & 3.0 & 3.00 & 2.94 \\
\hline $\begin{array}{l}\text { 4.7. Recognizing the } \\
\text { need for continuing } \\
\text { professional } \\
\text { development }\end{array}$ & 3.0 & 2.72 & 2.80 \\
\hline $\begin{array}{l}\text { 4.8. Showing } \\
\text { capability for } \\
\text { relationships and } \\
\text { communicating }\end{array}$ & 3.0 & 2.90 & 2.87 \\
\hline
\end{tabular}

\subsection{Analysis of the Results for Table 1 (the evaluation of scientific competencies)}

It is evident that all the students theoretically evaluate scientific competencies in general very 
highly and they are close to the evaluations of the teachers.

But on some scales, both the students and the teachers evaluated rather low some competencies. Those scales are:

1.2 (being up to date with the innovations in the subjects)

1.7 (knowing about innovative educational strategies)

1.8 (knowing about ICT)

It is really interesting to consider the evaluations for 1.6 scale (being trained in pedagogy and psychology for young people) where the evaluations of the students are higher than the teachers. On the scale 1.10 (knowing a foreign language well enough to teach), the evaluations of the teacher are higher than the students'.

The results of the first group demonstrate that the students possess a rather high level of theoretical knowledge on competencies. The received mean value for all scales is high, showing that the students appreciate a lot the importance of all competencies.

The second group (teachers' evaluations) demonstrates what problems the teachers deal with in their everyday work. Among the "learning to know" competencies they evaluate highly the traditional competencies of subject knowledge and their transmission.

It is interesting that low scores are demonstrated for the evaluation of such competencies as knowing ICT technologies, innovative educational strategies as well as psychological knowledge, which are considered to be key competencies for the twentyfirst-century education.

But, in fact, both the students and the teachers do not feel comfortable with some modern demands of competency-based education.

\subsection{Analysis of the Results for Table 2 (the evaluation of methodological competences)}

On this group of answers again we have the same picture, where the methodological competencies are evaluated very highly by the students before the pedagogical practice. From the methodological competencies, the highest scores received traditional competencies of managing classrooms, resolving the conflict in the classroom. In general, by the end of pedagogical practice, the answers of teachers and the students don't show much difference. In this case, the lowest scores got the following scales:

2.5 (developing initiatives for students with educational needs)

2.10.(using various student evaluation techniques and systems)

2.11.(exploring students' previous knowledge with initial evaluation)

\subsection{4.(designing teaching programmes)}

Again, the less evaluated competencies were designing teaching projects and ICT use.

\subsection{Analysis of the Results for Table 3 (the evaluation of social competencies)}

The evaluation of social competencies once again demonstrated that the traditional competencies such as facilitating communication with students and families as well as working in teams received the highest values. The fewer scores got scales such as:

3.2 (strengthening the students attitudes of critical citizenship).

3.5 (participating in education research projects)

3.8(participating in school/institutional projects)

3.9(participating in educational research projects)

After the pedagogical practice, we suggested the students reflect on their scores for the abovementioned scales and try to explain the reasons for their evaluations.

The answers demonstrated that these competencies are rather uncommon in the school practice and both the teachers and the students didn't understand how to activate them in their everyday work.

\subsection{Analysis of the results for Table 4 (Personal competencies)}

Among the personal competencies, the traditional values got the highest scores on the scales such as:

4.1.(knowing myself and my capabilities well)

4.2. (knowing how to take decisions individually)

4.3. (taking on responsibilities in the school, if necessary)

4.5. (having self-control and being emotionally balanced, resisting frustration)

4.6. (teaching students values (and being aware of them)

4.8. (showing capability for relationships and communicating)

On this table the lowest scores gained the scales:

4.4. (fostering a climate of respect and freedom of expression)

4.7. (recognizing the need for continuing professional development)

It is interesting that the evaluation of the scale for continuing professional development are rated low by the teachers and higher by the students. 
The students reflections on this scale after the pedagogical practice indicates that the younger generation is more interested in its future professional growth and understands the importance of continuing professional development which is one of the most appreciated competencies for the young specialists.

The evaluation by the students after the pedagogical practice (see Table 3 ) are very close to the teachers' evaluations nearly on all scales.

Their reflections are focused on the facts that most of the schools lack a proper quantity of ICT devices, the inclusive education pupils still don't have proper facilities in schools, the teachers seldom participate in research projects, the number of psychologists aren't enough and so on.

\section{Conclusions}

The analysis of the results demonstrated that the students possess a rather high level of theoretical knowledge of competencies but there is significant difference between their evaluations before and after the pedagogical practice and what is more interesting, by the end of the practice their evaluations became closer to the evaluations of the teachers', which demonstrate that in spite of adequate theoretical knowledge, the evaluation of competencies is not adequate to modern understanding of teaching and learning. Both the teachers and the students most appreciated the traditional system of knowledge delivery which indicates that there is still a significant gap between the theoretical knowledge and the practical use of the knowledge. The findings of our research indicate that there is dissatisfaction with the relationship between modern pedagogical theory and practice, accompanied by the need for its reconceptualization [4]. In today's information society, marked by rapid social change, it is particularly important to develop students' skills and attitudes to learning throughout life $[5,6,7]$ in new and increasingly uncertain situations. Thus, according to a recent OECD report (2012) on education in the twenty-first century, the importance of preparing students to be creative, think critically, solve problems, use tools for communication and collaboration, be socially responsible, and so forth, implies that teachers must abandon their traditional role of simply transmitting knowledge. In this study we tried to highlight the need for further experimental study of competencies. We recognize that out results are not sufficient enough to demonstrate all the difficulties of the formation of competencies. We recognise that this is a continuous and difficult process which needs further experimental study.

\section{References}

[1] Guerriero, S. (2017). Teachers' pedagogical knowledge: What it is and how it functions.
[2] Ferrández Berrueco, M. R., \& Sánchez-Tarazaga Vicente, L. (2014). Competencias docentes en secundaria. Análisis de perfiles de profesorado.

[3] Vecaldo, R. T., Andres, A. B., Carag, C. G., \& Caranguian, C. B. (2017). Pedagogical Competence and Academic Performance of Pre-Service Elementary Teachers in Tuguegarao City, Philippines. Asia Pacific Journal of Multidisciplinary Research, 5(1), 47-54.

[4] Ermenc, K. S., Vujisić, N. Ž., \& Spasenović, V. (2015). Theory, practice and competences in the study of pedagogy-views of Ljubljana and Belgrade university teachers. Center for Educational Policy Studies Journal, 5(2), 35-55.

[5] Aspin, D., \& Chapman, J. (2001, July). Lifelong learning: concepts, theories and values. In Proceedings of the 31st Annual Conference of SCUTREA (pp. 38-41). University of East London: SCUTREA.

[6] Knapper, C., \& Cropley, A. J. (2000). Lifelong learning in higher education. Psychology Press.

[7] Herrera, L., Lorenzo, O., \& Rodríguez, C. (2008). Las tutorías en el Espacio Europeo de Educación Superior: valoración de su implementación en la titulación de Maestro. Revista de Investigación Psicoeducativa, 6(1), 6585. 